\title{
REDESIGNING THE ROLES OF TUBERCULOSIS TREATMENT SUPPORTER IN INDONESIA
}

\author{
Redesain Peran Pengawas Menelan Obat pada Pasien Tuberkulosis di Indonesia \\ Khoiriningtyas Ayu Puspita ${ }^{1}$, Zeni Yanti², Nuzulul Kusuma Putri ${ }^{3}$, ${ }^{*}$ Stefanus Supriyanto ${ }^{4}$, Nurul Atiqah ${ }^{5}$ \\ 1,2The Indonesian Public Health Union of East Java Province, Indonesia \\ ${ }^{3,4}$ Faculty of Public Health, Universitas Airlangga, Indonesia \\ ${ }^{5}$ International Medical School, Management and Science University, Malaysia \\ *Correspondence: s.supriyanto@fkm.unair.ac.id
}

\begin{abstract}
Background: Indonesia is the third-highest rank country for tuberculosis. Many studies already compared the effectiveness of the Directly Observed Treatment-Short (DOTS) course with self-administered therapy (SAT) in tuberculosis treatment and pointed out that DOTS did not improve the succession rate (SR) significantly. The participation of a tuberculosis treatment supporter that has an important rule in the DOTS strategy to improve the patients' adherence in taking treatment should be reviewed.

Aims: The study aims to analyze the determination of environmental factors in the effectiveness of tuberculosis treatment which can lead to the program improvement issue.

Method: This research was a cross-sectional study conducted by involving 55 of 121 tuberculosis patients. The sampling frame was tuberculosis patients who were reported under the first and third quarters in Primary Healthcare Center of Tanah Kalikedinding as it had failed to reach the succession rate during 2012-2015.

Results: These findings indicated that the social environment of tuberculosis patients significantly contributed to their adherence to taking medicine. It showed that tuberculosis treatment supporters had an essential role in maintaining the patients' adherence. Tuberculosis treatment supporters who lived in one roof with the patient tended to get 2.265 times risk to be contagious. This study also pointed out that the physical environment had the highest determination in the success rate of treatment.

Conclusion: Modifying the physical environment of tuberculosis patients can be the greater alternative program to fight tuberculosis rather than the tuberculosis treatment supporters. Tuberculosis treatment supporters must be provided with universal protection due to their high-risk position to be contagious.
\end{abstract}

Keywords: treatment adherence, DOTS, patient environment, treatment effectiveness.

\section{ABSTRAK}

Latar Belakang: Indonesia merupakan negara dengan tuberkulosis tertinggi ketiga di dunia. Berbagai penelitian yang telah dilakukan membandingkan strategi DOTS dengan SAT dan menyatakan bahwa DOTS tidak meningkatkan keberhasilan pengobatan pasien tuberkulosis secara signifikan. Pengawas Minum Obat (PMO) memiliki peran utama dalam strategi DOTS, sehingga partisipasi PMO dalam meningkatkan kepatuhan pasien minum obat perlu ditelaah kembali.

Tujuan: Penelitian ini bertujuan untuk menganalisis determinasi faktor lingkungan dalam efektivitas pengobatan tuberkulosis yang mengarah pada isu perbaikan program.

Metode: Penelitian ini merupakan penelitian cross sectional dengan menggunakan metode simple random sampling yang menghasilkan 55 sampel dari 121 populasi pasien tuberkulosis. Responden merupakan pasien tuberkulosis yang terlaporkan pada buku register TB-01 dan TB-03 di Puskesmas Tanah Kalikedinding sebagai puskesmas yang belum mencapai keberhasilan pengobatan dalam 2012-2015.

Hasil: Hasil dari penelitian ini menunjukkan lingkungan sosial pasien berpengaruh signifikan terhadap kepatuhan pasien minum obat yang menunjukkan PMO berperan penting dalam kepatuhan pasien minum obat. PMO yang tinggal serumah dengan pasien memiliki risiko 2, 265 kali tertular tuberkulosis. Penelitian ini juga menunjukkan bahwa lingkungan fisik pasien tuberkulosis merupakan determinan tertinggi dalam keberhasilan pengobatan (SR) Kesimpulan: Modifikasi lingkungan fisik pasien tuberkulosis dapat menjadi program alternatif terbaik untuk menghadapi tuberculosis dibandingkan dengan PMO. Adanya PMO harus dipastikan mendapatkan perlindungan yang menyeluruh mengingat tinggiya risiko untuk tertular tuberkulosis.

Kata kunci: DOTS, kepatuhan minum obat, lingkungan pasien, efektivitas pengobatan. 


\section{INTRODUCTION}

Tuberculosis (TB) is one of the top 10 causes of death worldwide. In fact, 10 million people were infected by TB, and 1.6 million died from the disease (including 0.3 million among people with HIV) in 2017 (World Health Organization, 2018). Indonesia was the country with the third-highest TB incidence rate after India and China in the 2018 Global Tuberculosis Report by WHO. The number of new TB cases in Indonesia reached 420,994 cases in 2017 (Ministry of Health of the Republic of Indonesia, 2018).

In dealing with this condition, the World Health Organization has implemented a tuberculosis control strategy by holding the Directly Observed Treatment-Short (DOTS) course since 1993 (World Health Organization, 1999). Indonesia has used DOTS as a TB control strategy since 2000 (Ministry of Health of the Republic of Indonesia, 2011). DOTS has 5 main components which include; political commitment, with increasing and continuing funding; case finding through quality microscopic phlegm examination; standard treatment with supervision and support for patients; effective management and availability of Anti Tuberculosis Medicine (ATM) systems; and the records and reports of monitoring system that provide an assessment of patient treatment outcomes and program performance (World Health Organization, 1999). One of the most critical aspects of the DOTS strategy is the presence of Tuberculosis Treatment Supporter. Medicine intake supervisors, who are the health workers or cadres or family members selected by TB patients, take drugs regularly, on schedule, for the full duration of the treatment. Besides, they also need to listen and encourage their patients as part of their support.

The study conducted in India by Parida et al., (2014) identified that among 75 TB patients as respondents for each DOTS and SAT (SelfAdministered Therapy) strategy, approximately $70.7 \%$ of treatments which use DOTS strategy was complete. Meanwhile, the respondents who use SAT strategy only completed about $68 \%$ of treatment (Parida et al., 2014). From another similar study, it was stated that patients adhere more easily to the regimen, then consequently increase the success rate in treatment. Several studies also pointed out that DOTS was more effective than SAT (Tian et al., 2014). However, DOTS had not signified the increase of the cure rates and reduced dropout rates or lower mortality, which are the factors that would prove the treatment effectiveness.

In the research conducted by Coêlho et al., (2017) regarding the differences of Directly Observed Treatment with Self-Administered Therapy Outcomes in Pulmonary Tuberculosis Patients using meta-analysis, it indicates that treatment success, identified only in the healed and completed treatment group, was more significant among patients under the SAT regimen (OR 1.22,
$95 \% \mathrm{Cl} 1.07$ to 1.40). Similar studies were also published by Karumbi and Garner (2015) that revealed TB cure with SAT was low across all studies, and direct observation did not substantially improve the score (OR 1.08, 95\% Cl 0.91 to 1.27 ). Meanwhile, the treatment completion indicated a similar pattern, ranging from $59 \%$ to $78 \%$ in the selftreatment groups, and DOTS did not improve the score (RR $1.07,95 \% \mathrm{Cl} 0.96$ to 1.19 ).

Treatment supervision is one of the pillars of the DOTS strategy; there may be differences in the quality of the supervision provided, considerably influencing the results represented by complete healing (Coêlho et al., 2017). DOTS has been criticized as a passive model within public health services since it often only delivers the appropriate drugs without taking into account some important social components of the disease which may lead to a low success rate, social stigma, and lack of moral support by family members unwilling to modify living conditions and habits (Coêlho et al., 2017).

The patients with TB more likely to choose a family member as a TB treatment supporter. It was revealed in research which involved 773 patients, $86.8 \%$ picked a family supporter, $7.63 \%$ selected community worker, and $5.56 \%$ chose health facility workers as their treatment supporters. Women and younger patients prefer their family members to supervise their treatments (Hussain et al., 2018). Therefore, the participation of tuberculosis treatment supporters which aim to improve the patients' adherence in taking treatment should be reviewed. Environmental aspects were one of the important factors that were neglected.

Environmental conditions that play an important role in disease development were humidity and the number of people living in the house. Poor ventilation and overcrowded house increase the exposure possibility to Mycobacterium tuberculosis (MTB) and the disease progression (Srivastava, Kant, and Verma, 2015). In the study conducted by Madhona, Ikhwan, and Aminin (2017), it denoted that there was a significant correlation between environmental factors, such as residential density, lighting, and humidity with TB incidence. Thus, the environmental factors should be observed.

In the Primary Healthcare Center of Tanah Kalikedinding, it was identified that the success rate for TB Treatment had not met the standard during 2012-2015. The succession rate was a measurement of TB treatment effectiveness. The study aims to analyze the determination of environmental factors in the tuberculosis therapy effectiveness which could lead to the program improvement issue. This research provides recommendations about the vital role of environmental factors in TB patients' adherence and treatment effectiveness. The findings can encourage the program innovations to TB treatment supporter role in Indonesia. 


\section{METHOD}

This research was a cross-sectional with systematic random sampling, which involved 55 out of 121 tuberculosis patients as respondents. The sampling frame was the tuberculosis patients who reported under the first and third quarters in Primary Healthcare Center of Tanah Kalikedinding in 20152016. The research site was selected by considering that it was the only Primary Healthcare Centers in Surabaya, which failed to reach the succession rate in 2012-2015.

The study obtained primary and secondary data. The primary data in this study were taken through questionnaires and observation instruments on 55 respondents to assess the determinants of patients' adherence and treatment effectiveness. The result for patients' adherence was categorized as poor ( $<6$ of total scores) and good ( $\geq 6$ of total scores) category. Meanwhile, the results for treatment effectiveness were categorized as ineffective (detected with positive acid-fast bacilli/AFB after treatment) and effective category (detected with negative acid-fast bacilli/AFB after treatment). Additionally, the characteristics of tuberculosis treatment supporters were also assessed to identify tuberculosis treatment supporters' risks. The canvassing method was used to collect data from the respondents.

The secondary data collected in this study concerns the succession rate. The data were obtained from TB register 01 and TB 03 in the Primary Healthcare Center of Tanah Kalikedinding Surabaya to select the respondents. The statistical analysis utilized in this study was a Binary Logistic Regression test with $\alpha=0.05$.

\section{RESULTS AND DISCUSSION}

There were 55 respondents participated in this study. This research signified the results of the factors that caused adherence and the effectiveness of tuberculosis patient healing.

\section{Adherence Determinants}

The determinant variables of treatment adherence involved in this study consisted of age, sex, education level, health education during treatment, family support, and the presence of TB treatment supporters. This study discovered that, based on the respondents' age ( $\operatorname{sig}=0.232$; $\mathrm{B}=0.131$ ), approximately $80.0 \%$ of the respondents aged 26-35 years old had good adherence. In accordance to sex variable $(\mathrm{sig}=0.998 ; \mathrm{B}=0.002)$, about $56.0 \%$ of male respondents had poor adherence. Meanwhile, based on the education level (sig=0.916; $B=0.096)$, about $64.7 \%$ of respondents who were elementary school graduates had poor adherence. In terms of the variable of health education during treatment $(\mathrm{sig}=0.014$; $\mathrm{B}=1.822$ ), about $74.1 \%$ of respondents with infrequent health education had poor adherence. Regarding the variable of family support ( $\mathrm{sig}=0.047$;
$\mathrm{B}=0.064$ ), around $77.8 \%$ of respondents with lowincome family support had poor adherence. On the other hand, the variable of patients provided with TB treatment supporter ( $\mathrm{sig}=0.008 ; \mathrm{B}=3.084), 93.3 \%$ of respondents with no TB treatment supporter indicated the poor adherence. The further results for treatment adherence determinants were presented in Table 1.

Based on that result, it connoted that health education during treatment ( $\mathrm{sig}=0.014 ; \mathrm{B}=1.822$ ), family support ( $\mathrm{sig}=0.047 ; \mathrm{B}=0.064)$, and the presence of TB treatment supporter (sig $=0.008$; $B=3.084$ ) were the factors that influence patients' adherence $(<\alpha 0.05)$. Other studies suggested a similar result to these findings. In a study conducted in the Community Center for Lung Health or Balai Besar Kesehatan Paru Masyarakat (BKPM) of Pati, it was indicated that health education during treatment affects the treatment adherence with $\mathrm{p}$ value $<0.043$ (Jose et al., 2019). The study conducted in Primary Healthcare Center of Motoboi implied that family support influence patients' adherence with $p$-value $=0.001$ (Irnawati, Siagian, and Ottay, 2016). In addition, the study conducted in Primary Healthcare Center of Sario revealed that the availability of supervisors or TB treatment supporters affected patients' adherence with $p$ value $=0.001$ (Yoisangadji, Maramis and Rumayar, 2016). Thus, the social environment of tuberculosis patients significantly contributed to their adherence to taking medicine. It suggested that the medicine intake supervisor had an important role in maintaining the patients' adherence.

\section{Treatment Effectiveness Determinants}

Treatment effectiveness is the success of any treatment to cure the patients or improve patients' conditions (Crum and Zuckerman, 2017). The variables involved in this study to determine treatment effectiveness included individual factors and environmental factors. Individual factors consisted of the variable of alcohol consumption, nutritional status, and comorbidities. Environmental factors consist of the variable of health care access, household contact, and house condition. In this study, the individual factors, such as nutritional status treatment $(\mathrm{sig}=0.023 ; \quad \mathrm{B}=3.247)$ and comorbidities factor ( $\mathrm{sig}=0.006 ; \mathrm{B}=3.719)$ strongly affected treatment effectiveness $(\alpha<0.05)$.

The environmental factors in this study signified that $76.2 \%$ of the respondents who never smoked had effective treatment (sig=1.000; $\mathrm{B}=0.000$ ). Approximately $69.2 \%$ of the respondents who never consume alcohol had effective treatment ( $\mathrm{sig}=0.996 ; \quad \mathrm{B}=19.315$ ), and $92.6 \%$ of the respondents with normal nutrition status had effective treatment ( $\mathrm{sig}=0.023 ; \mathrm{B}=3.247)$. On the other side, $86.5 \%$ of the respondents without comorbidities factor had effective treatment $(\mathrm{Sig}=0.006 ; \mathrm{B}=3.719)$. This research denoted that $73.7 \%$ of the respondents with good health care access had effective treatment (sig=0.995; $B=32.756)$. 
Table 1. The Adherence Determinants on Tuberculosis Patients under the First and Third Quarter in Primary Healthcare Center of Tanah Kalikedinding during 2015-2016.

\begin{tabular}{|c|c|c|c|c|c|c|c|c|}
\hline \multirow{3}{*}{ Variable } & \multicolumn{4}{|c|}{ Adherence } & \multirow{3}{*}{ - Total } & \multirow{3}{*}{$\%$} & \multirow{3}{*}{ B } & \multirow{3}{*}{ Sig. } \\
\hline & \multicolumn{2}{|c|}{ Poor } & \multicolumn{2}{|c|}{ Good } & & & & \\
\hline & $\mathbf{N}$ & $\%$ & $\mathbf{n}$ & $\%$ & & & & \\
\hline \multicolumn{9}{|l|}{ Age } \\
\hline $17-25$ years & 4 & $36.4 \%$ & 7 & $63.6 \%$ & 11 & $100.0 \%$ & \multirow{5}{*}{0.131} & \multirow{5}{*}{0.232} \\
\hline $26-35$ years & 1 & $20.0 \%$ & 4 & $80.0 \%$ & 5 & $100.0 \%$ & & \\
\hline $36-45$ years & 11 & $68.8 \%$ & 5 & $31.3 \%$ & 16 & $100.0 \%$ & & \\
\hline $46-55$ years & 9 & $52.9 \%$ & 8 & $47.1 \%$ & 17 & $100.0 \%$ & & \\
\hline $56-65$ years & 4 & $40.0 \%$ & 6 & $60.0 \%$ & 10 & $100.0 \%$ & & \\
\hline \multicolumn{9}{|l|}{ Sex } \\
\hline Male & 14 & $56.0 \%$ & 11 & $44.0 \%$ & 25 & $100.0 \%$ & \multirow[b]{2}{*}{0.002} & \multirow[b]{2}{*}{0.998} \\
\hline Female & 15 & $50.0 \%$ & 15 & $50.0 \%$ & 30 & $100.0 \%$ & & \\
\hline \multicolumn{9}{|l|}{ Education level } \\
\hline Senior high school & 11 & $47.8 \%$ & 12 & $52.2 \%$ & 23 & $100.0 \%$ & \multirow{4}{*}{0.096} & \multirow{4}{*}{0.916} \\
\hline Junior high school & 6 & $42.9 \%$ & 8 & $57.1 \%$ & 14 & $100.0 \%$ & & \\
\hline Elementary school & 11 & $64.7 \%$ & 6 & $35.3 \%$ & 17 & $100.0 \%$ & & \\
\hline Never attend school & 1 & $100.0 \%$ & 0 & $0.0 \%$ & 1 & $100.0 \%$ & & \\
\hline \multicolumn{9}{|c|}{$\begin{array}{l}\text { Health education during } \\
\text { treatment }\end{array}$} \\
\hline infrequent $(<5$ times) & 20 & $74.1 \%$ & 7 & $25.9 \%$ & 27 & $100.0 \%$ & \multirow{2}{*}{1.822} & \multirow{2}{*}{0.014} \\
\hline frequent & 9 & $32.1 \%$ & 19 & $67.9 \%$ & 28 & $100.0 \%$ & & \\
\hline \multicolumn{9}{|l|}{ Family support } \\
\hline Poor & 14 & $77.8 \%$ & 4 & $22.2 \%$ & 18 & $100.0 \%$ & \multirow{2}{*}{0.064} & \multirow{2}{*}{0.047} \\
\hline Good & 15 & $40.5 \%$ & 22 & $59.5 \%$ & 37 & $100.0 \%$ & & \\
\hline \multicolumn{9}{|c|}{$\begin{array}{l}\text { Provided with TB treatment } \\
\text { supporter }\end{array}$} \\
\hline No & 14 & $93.3 \%$ & 1 & $6.7 \%$ & 15 & $100.0 \%$ & & \\
\hline Yes & 15 & $37.5 \%$ & 25 & $62.5 \%$ & 40 & $100.0 \%$ & 3.084 & 0.008 \\
\hline
\end{tabular}

Table 2. The Treatment Effectiveness Determinants on Tuberculosis Patients under The First and Third Quarter in Primary Healthcare Center of Tanah Kalikedinding during 2015-2016.

\begin{tabular}{|c|c|c|c|c|c|c|c|c|}
\hline \multirow{3}{*}{ Variable } & \multicolumn{4}{|c|}{ Treatment Effectiveness } & \multirow{3}{*}{ Total } & \multirow{3}{*}{$\%$} & \multirow{3}{*}{ B } & \multirow{3}{*}{ Sig. } \\
\hline & \multicolumn{2}{|c|}{ Ineffective } & \multicolumn{2}{|c|}{ Effective } & & & & \\
\hline & $\mathbf{N}$ & $\%$ & $\mathbf{n}$ & $\%$ & & & & \\
\hline \multicolumn{9}{|l|}{ Individual Factor } \\
\hline \multicolumn{9}{|l|}{ Smoking } \\
\hline Active smoker & 8 & $61.5 \%$ & 5 & $38.5 \%$ & 13 & $100.0 \%$ & 0.000 & 1.000 \\
\hline Never smoke & 10 & $23.8 \%$ & 32 & $76.2 \%$ & 42 & $100.0 \%$ & & \\
\hline \multicolumn{9}{|l|}{$\begin{array}{l}\text { Alcohol } \\
\text { consumption }\end{array}$} \\
\hline $\begin{array}{l}\text { Infrequent (once } \\
\text { in month) }\end{array}$ & 2 & $66.7 \%$ & 1 & $33.3 \%$ & 3 & $100.0 \%$ & 19.315 & 0.996 \\
\hline Never & 16 & $30.8 \%$ & 36 & $69.2 \%$ & 52 & $100.0 \%$ & & \\
\hline \multicolumn{9}{|l|}{ Nutritional status } \\
\hline Underweight & 16 & $57.1 \%$ & 12 & $42.9 \%$ & 28 & $100.0 \%$ & 3.247 & 0.023 \\
\hline Normal & 2 & $7.4 \%$ & 25 & $92.6 \%$ & 27 & $100.0 \%$ & & \\
\hline \multicolumn{9}{|l|}{ Comorbidities } \\
\hline No & 5 & $13.5 \%$ & 32 & $86.5 \%$ & 37 & $100.0 \%$ & 3.719 & 0.006 \\
\hline Yes & 13 & $72.2 \%$ & 5 & $27.8 \%$ & 18 & $100.0 \%$ & & \\
\hline \multicolumn{9}{|l|}{$\begin{array}{l}\text { Environment Factor } \\
\text { Health care access }\end{array}$} \\
\hline Poor & 8 & $47.1 \%$ & 9 & $52.9 \%$ & 17 & $100.0 \%$ & 32.756 & 0.995 \\
\hline Good & 10 & $26.3 \%$ & 28 & $73.7 \%$ & 38 & $100.0 \%$ & & \\
\hline \multicolumn{9}{|l|}{ Household contact } \\
\hline Yes & 11 & $57.9 \%$ & 8 & $42.1 \%$ & 19 & $100.0 \%$ & 2.265 & 0.041 \\
\hline No & 7 & $19.4 \%$ & 29 & $80.6 \%$ & 36 & $100.0 \%$ & & \\
\hline \multicolumn{9}{|l|}{ House condition } \\
\hline Unlivable house & 15 & $62.5 \%$ & 9 & $37.5 \%$ & 24 & $100.0 \%$ & 3.425 & 0.024 \\
\hline Livable house & 3 & $9.7 \%$ & 28 & $90.3 \%$ & 31 & $100.0 \%$ & & \\
\hline
\end{tabular}


Moreover, $80.6 \%$ of the respondents without household contact had effective treatment ( $\mathrm{sig}=0.041 ; \mathrm{B}=2.265$ ), and about $90.3 \%$ of the respondents with the livable house had effective treatment ( $\mathrm{sig}=0.024 ; \mathrm{B}=3.425$ ). Meanwhile, from the environmental factor, it indicated that the variable of household contact ( $\mathrm{sig}=0.041 ; \mathrm{B}=2.265$ ) and house condition ( $\mathrm{sig}=0.024 ; \quad \mathrm{B}=3.425$ ) significantly affected treatment effectiveness $(\alpha<0.05)$. The complete data of treatment effectivity were presented in Table 2. These findings were similar to the results from other studies which pointed out that environmental factors have strongly affected the treatment effectiveness of TB patients (Srivastava, Kant, and Verma, 2015). It was also similar to the study conducted in Tanjungpinang City by Madhona, Ikhwan, and Aminin (2017). This study suggested that the physical environment (residential density, humidity, and lighting) has a significant correlation with TB incidence.

This study also suggested that treatment adherence strongly affected treatment effectiveness ( $\mathrm{sig}=0.003 ; \mathrm{B}=0.122$ ). It indicated that the respondents with treatment adherence had a probability of 8.196 times higher $(1 / 0.122)$ to acquire effective treatment. A similar study also suggests that according to these findings, it can be concluded that determinants of treatment adherence and treatment effectiveness include the provider factor, environmental factor, and patient factor. By referring to each of those variables, there were influences both on treatment adherence and treatment effectiveness, as it is shown in Figure 1.

From Figure 1, It can be seen that the environmental factors were the factors with variables that were proven as the determinant of treatment adherence and treatment effectiveness. Those variables were family support, treatment supporter, household contact, and house condition. In terms of the variable of house condition $(B=3.425)$, the results indicated that TB patients with the livable house had probability 3.425 times higher of having effective treatment than those with the unlivable house. The presence of TB treatment supporter $(\mathrm{B}=3.084)$ also could lead to a probability of 3.084 times higher to attain the patients' treatment adherence than without a TB treatment supporter. It implied that the treatment supporter had a vital role in the patients' adherence. In contrast, this research, based on the variable of household contact $(B=2.265)$, revealed that the respondents without household contact had the probability of 2.265 times to get effective treatment, otherwise, it could be stated that it had the probability $1 / 2.265$ times to ineffective treatment.

\section{TB Treatment Supporters}

This study identified that TB treatment supporters were the highest determinant of TB patients' adherence, while environmental factors were the highest determinant for treatment effectiveness. Nevertheless, it was identified that TB treatment supporters were vulnerable to their characteristics. This study recognized that TB treatment supporters had differences in characteristics that consisted of status, household contact, job, and training about TB. Approximately $92.5 \%$ of treatment supporters were the family member of TB patients. Besides, $77.5 \%$ of treatment supporters lived in the same roof with TB patients. These findings were similar to research conducted by Hussain et al., (2018) that from 773 patients incorporated into the study, $86.8 \%$ picked the family supporters, $7.63 \%$ selected community workers and $5.56 \%$ chose health facility workers as their treatment supporters. TB treatment supporters' knowledge indicated that $42.5 \%$ of treatment supporters did not have any training about TB. Other similar studies concerning TB treatment supporters, TB patients' knowledge, and TB treatment adherence suggested that there was a correlation between TB treatment supporters' knowledge with patients' adherence (Prihantoro, 2013; Lupitayanti and Putra, 2014). The further results for TB treatment supporters were displayed in Table 3.

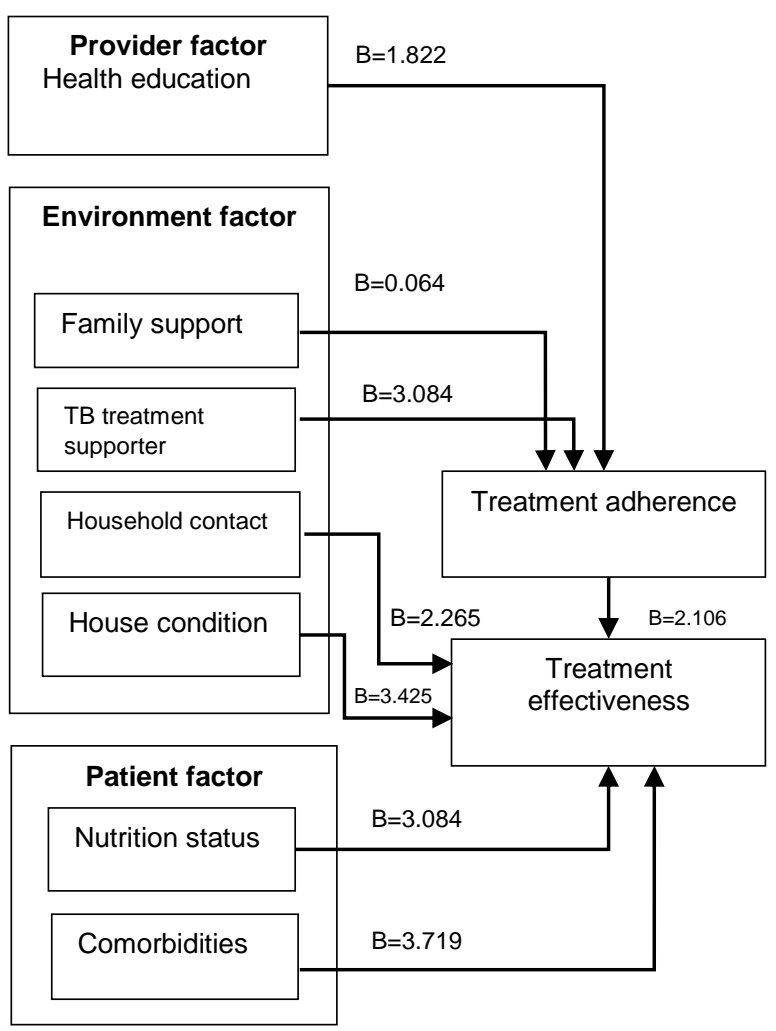

Figure 1. The Determinant Variables of Treatment Adherence and Treatment Effectiveness on Tuberculosis Patients under the First and Third Quarter in Primary Healthcare Center of Tanah Kalikedinding in 2015-2016.

Based on the household contact with treatment effectiveness $(B=2.265)$, it signified that TB patients were more likely 2.265 times higher to have ineffective treatment. Treatment supporters $(77.5 \%)$ were more likely had contact intensively with TB patients. Hence, it means that a tuberculosis treatment supporters living in the 
same house with the patient had 2, 265 times higher risk to contact with TB patient and to be infected. Furthermore, TB treatment supporter characteristics were presented in Table 3. Another study revealed that 7 out of 100 contacts living in the same house with a TB patient developed bacteriologically-confirmed pulmonary TB (Beyanga et al., 2018). This study denoted that household contact with TB patients tended to get contagion of TB transmission without universal protection and functional knowledge.

The main finding of this research indicated that the environmental factors had been considered as the significant determinants of TB treatment effectiveness. This research also pointed out that TB treatment supporters considered as a significant determinant of treatment adherence were highly risked to contagion.

In the study conducted by Deun and Rieder (2012), the DOTS strategy remained an effective TB control strategy to be applied globally by emphasizing the implementation of the five main elements of the DOTS strategy. The five main elements in the DOTS strategy were united, thus, they could not be used partially. Hence, it was intended to achieve success in TB treatment. The existence of a TB treatment supporter was one of the main pillars, but the other four DOTS pillars must still be fulfilled. In the research related to the implementation of the DOTS strategy in developing countries, it was stated that the DOTS strategy was a cornerstone or a strategic base to be implemented by taking into account the characteristics and limitations of the related developing countries (Out, 2013).

Table 3. The Characteristics of Treatment Supporters on Tuberculosis Patients in Primary Healthcare Center of Tanah Kalikedinding.

\begin{tabular}{|c|c|c|}
\hline $\begin{array}{l}\text { Treatment Support } \\
\text { Characteristics }\end{array}$ & $\mathbf{n}$ & $\%$ \\
\hline \multicolumn{3}{|l|}{ Status } \\
\hline Family Member & 37 & $92.5 \%$ \\
\hline Neighbour & 3 & $7.5 \%$ \\
\hline \multicolumn{3}{|l|}{ Household Contact } \\
\hline Living on the same roof & 31 & $77.5 \%$ \\
\hline Separated & 9 & $22.5 \%$ \\
\hline \multicolumn{3}{|l|}{ Job } \\
\hline Improper & 18 & $45.0 \%$ \\
\hline Proper & 22 & $55.0 \%$ \\
\hline \multicolumn{3}{|l|}{ Training about TB } \\
\hline Never & 17 & $42.5 \%$ \\
\hline Ever & 23 & $57.5 \%$ \\
\hline
\end{tabular}

The prevention strategy by WHO with End TB strategy in 2014 was a development program from STOP TB Partnership Program in 2006. The STOP TB strategy had pursued a high quality of DOTS in expansion and enhancement. It showed that DOTS strategy implementations should be in high quality and be implemented completely (World Health Organization, 2006, 2014). The End TB strategy was launched in 2015 as a strategy to continuously reach a vision of the world free TB. In line with Sustainable Development Goals (SDGs), it will also become a milestone to reduce tuberculosis incidence rate up to $90 \%$ in 2035 . In this strategy, the Infection Preventive Control (IPC) program emphasized the aspect of administrative controls, environmental controls, and respiratory protection (World Health Organization, 2019). It meant that environmental aspects and preventions had become the primary concerns in TB controls that were in accordance with the results of this study. On its implementation, the 2018 Global Tuberculosis Report explained that countries that implemented preventive strategy had an improvement in reducing TB incidence rate (World Health Organization, 2018).

Indonesia in applying the DOTS strategy nearly reached Millennium Development Goals (MDGs) targets in 2010 (Ministry of Health of Republic Indonesia, 2010). In its developments, 5 pillars of DOTS had been applied. Unfortunately, in implementing these pillars, there were still obstacles that were closely related to the constraints on TB treatment supporters, i.e., the limited number of health workers, and inadequate political commitment in demonstrating TB incidents (Prameswari, 2018).

The role of TB treatment supporters in STOP TB program in Indonesia included: supervising TB patients to take medication regularly until they finished their treatments; encouraging patients to seek regular treatment; reminding the patient to recheck phlegm at the specified time; providing the counseling session to family members of TB patients who had suspicious symptoms of TB to immediately direct them to the healthcare facilities (Ministry of Health of Republic Indonesia, 2011). Based on the description of the role, it could be inferred that TB treatment supporters had not been involved in prevention efforts through the modification of environmental factors. The primary role of TB treatment supporters was still focused on patients' adherence to taking medicine. Considering that TB treatment supporters had a high risk of contracting TB, the role related to self-protection through concern for environmental factors was required to be. TB treatment supporters must be equipped with adequate knowledge and roles, therefore, they could increase the patients' adherence in taking medicine without placing themselves at high risk for TB contact.

Based on its application in Indonesia as a developing country with the appropriate conditions, Indonesia applied the environmental modification of living environments through existing TB control programs. The program should involve the role of TB treatment supporters which put attention on environmental factors and provide them universal protection, so they would not be infected by TB. According to The End TB of WHO strategy (2014), an environmental aspect that should be observed or intervened was about the ventilation system and the use of Upper-room Germicidal Ultraviolet (GUV) to reduce Mycobacterium tuberculosis transmission and to support TB patient treatment effectiveness. An environmental aspect that should be implemented as well related to TB treatment 
supporter role was about respiratory protection. In this aspect, in line with international standards on occupational safety and health, it was vital that national health care authorities must make use of particulate respirators for health workers and the community at risk (including medicine intake supervisor) only when a respiratory protection program could be put in place. Attempting to establish one without the other may lead to an overreliance on respirators and give a false sense of protection. In the implementation of the policy related to respiratory protection, the implementation should be supported with the enabling factors (material, resources) and be controlled as The End TB Strategy from WHO recommends it (2014).

\section{CONCLUSION}

These findings suggest that the social environment of tuberculosis patients significantly contributes to their adherence to taking medicine. It indicates that the tuberculosis treatment supporters have a vital role in maintaining the patients' adherence. Unfortunately, tuberculosis treatment supporters living under the same roof with the patients tend to 2,265 times riskier to be infected. On the other hand, this study also points out that the physical environment has the highest determination in the success rate of treatment. The alternative suggestion is to redesign the role of TB treatment supporters based on these findings by implementing a preventive strategy recommended by $\mathrm{WHO}$ and by paying attention to the environmental issue related to TB in the strategic plan for TB treatment supporters. More findings of this topic might be helpful for program improvement. Thus, the further researches about redesigning TB treatment supporter role are necessary to be conducted.

\section{CONFLICT OF INTEREST}

The authors state that there is no conflict of interest in this article.

\section{REFERENCES}

Beyanga, M. et al. (2018) 'Investigation of Household Contacts of Pulmonary Tuberculosis Patients Increases Case Detection in Mwanza City, Tanzania', BMC Infectious Disease. BMC Infectious Diseases, 18(110), pp. 1-8. doi: 10.1186/s12879-018-3036-6.

Coêlho, A. A. et al. (2017) 'A Meta-Analysis of Directly Observed Treatment vs . Self- Administered Therapy Outcomes in Pulmonary Tuberculosis Patients', Journal of Infectious Diseases and Epidemiology, 3(1), pp. 1-7. doi: $10.23937 / 2474-3658 / 1510027$

Crum, A. and Zuckerman, B. (2017) 'Changing Mindsets to Enhance Treatment Effectiveness', JAMA, 317(20), pp. 20632064. doi: $10.1001 /$ jama.2017.4545.

Deun, A. Van and Rieder, H. L. (2012) 'DOT, S , or
DOTS ?', Public Health Action, 2(1), pp. 34. doi: 10.5588/pha.12.0007.

Hussain, S. et al. (2018) 'Type of Treatment Supporters in Successful Completion of Tuberculosis Treatment: A Retrospective Cohort Study in Pakistan', The Open Infectious Diseases Journal, 10, pp. 37-42. doi: 10.2174/1874279301810010037.Type.

Irnawati, N. M., Siagian, I. E. T. and Ottay, R. I. (2016) 'Pengaruh Dukungan Keluarga Terhadap Kepatuhan Minum Obat Pada Penderita Tuberkulosis di Puskesmas Motoboi Kecil Kota Kotamobagu', Jurnal Kedokteran Komunitas dan Tropik, 4(1).

Jose, J. et al. (2019) 'Medication Adherence To Anti Tuberculosis Treatment Among Tuberculosis Patients In An Urban Private Tertiary Referral Hospital: A Prospective Cross Sectional Study', World Journal of Pharmaceutical Research, 8(6), pp. 598612. doi: 10.20959/wjpr20196-14750.

Karumbi, J. and Garner, P. (2015) 'Directly Observed Therapy for Treating Tuberculosis', Cochrane Database of Systematic Reviews. Art: John Wiley \& Sons, Ltd, (5). doi: 10.1002/14651858.CD003343.pub4.

Lupitayanti, L. E. and Putra, I. W. G. A. E. (2014) 'Kinerja Pengawas Menelan Obat (PMO) Penderita TB Paru BTA+ Di Puskesmas I Denpasar Selatan Tahun 2012', Community Health, 2(1), pp. 141-147.

Madhona, R., Ikhwan, Z. and Aminin, F. (2017) 'Physical Environment Home and Incidence of TB Disease in Tanjungpinang District', in Advances in Health Sciences Research. Atlantis Press. doi: 10.2991/phico16.2017.77.

Ministry of Health of Republic Indonesia (2010) Pengendalian TB di Indonesia Mendekati MDGs. Jakarta. Available at: http://www.depkes.go.id/article/print/857/pen gendalian-tb-di-indonesia-mendekati-targetmdg.html.

Ministry of Health of Republic Indonesia (2011) Pedoman Nasional Pengendalian Tuberkulosis. Jakarta: Kementerian Kesehatan Republik Indonesia Direktorat Jenderal Pengendalian Penyakit dan Penyehatan Lingkungan.

Ministry of Health of Republic Indonesia (2018) 'Tuberkulosis', Infodatin, p. 4. Available at: http://www.depkes.go.id/download.php?file= download/pusdatin/infodatin/infodatin tuberkulosis 2018.pdf.

Out, A. A. (2013) 'Is The Directly Observed Therapy Short Course ( DOTS ) an Effective Strategy for Tuberculosis Control in a Developing Country?', Asian Pacific Journal of Tropical Disease, 3(3), pp. 227-231. doi: 10.1016/S2222-1808(13)60045-6.

Parida, A. et al. (2014) 'Comparison of Directly Observed Treatment Short Course ( DOTS ) with Self-Administered Therapy in Pulmonary Tuberculosis in Udupi District of Southern India', Journal of Clinical and Diagnostic Research, 8(8), pp. 29-31. doi: 
10.7860/JCDR/2014/8865.4721.

Prameswari, A. (2018) 'The Evaluation of Directly Observed Treatment Short-Course ( DOTS ) Implementation for TB in Hospital X', Jurnal Medicoeticolegal dan Manajemen Rumah Sakit, 7(2), pp. 93-101. doi: 10.18196/jmmr.7261.

Prihantoro, A. (2013) Hubungan Tingkat Pengetahuan Pengawas Minum Obat (PMO) Penderita TBC dengan Perilaku Pencegahan Penularan TBC di Wilayah Kerja Puskesmas Jatiyoso Kabupaten Karanganyar. Undergraduate Thesis. University of Muhammadiyah Surakarta.

Srivastava, K., Kant, S. and Verma, A. (2015) 'Role of Environmental factors in Transmission of Tuberculosis', Dynamics of Human Health, 2(4).

Tian, J. et al. (2014) 'Effectiveness of Directly Observed Treatment of Tuberculosis: A Systematic Review of Controlled Studies Effectiveness of Directly Observed Treatment of Tuberculosis: A Systematic Review of Controlled Studies', International Journal of Tuberculosis and Lung Disease, 18(9). doi: 10.5588/ijtld.13.0867.

World Health Organization (1999) What is DOTS ? A Guide to Understanding the WHOrecommended TB Control Strategy Known as DOTS. 1st edn. Geneva: World Health Organization.

World Health Organization (2006) The Stop TB Strategy Building on and enhancing DOTS to meet the TB-related Millennium Development Goals. Geneva: World Health Organization. Available at: https://www.who.int/tb/strategy/stop_tb_strat egy/en/.

World Health Organization (2014) The End TB Strategy- Global strategy and targets for tuberculosis prevention, care and control after 2015. Geneva: World Health Organization.

World Health Organization (2018) Global Tuberculosis Report 2018. Geneva.

World Health Organization (2019) WHO Guidelines On Tuberculosis Infection Prevention and Control- The End TB Strategy. Geneva: World Health Organization.

Yoisangadji, A. S., Maramis, F. R. R. and Rumayar, A. A. (2016) 'Hubungan Antara Pengawas Menelan Obat (PMO) dan Peran Keluarga dengan Kepatuhan Minum Obat pada Pasien Tuberkulosis di Wilayah Kerja Puskesmas Sario Kota Manado', PHARMACON Jurnal IImiah Farmasi, 5(2), pp. 138-143. 